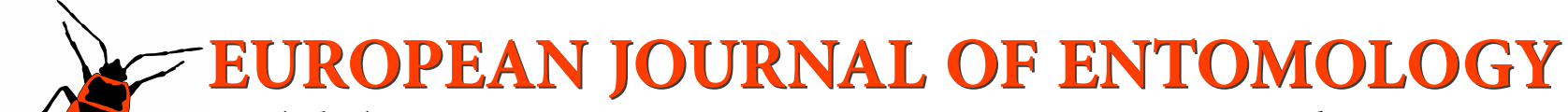 \\ ISSN (online): 1802-8829 \\ http://www.eje.cz \\ Eur. J. Entomol. 114: 222-229, 2017 \\ doi: 10.14411/eje.2017.027 \\ ORIGINAL ARTICLE
}

\section{Fitness traits of Drosophila melanogaster (Diptera: Drosophilidae) after long-term laboratory rearing on different diets}

\author{
Jelena TRAJKOVIĆ ${ }^{1}$, Vukica VUJiĆ ${ }^{1}$, Dragana MILIČIĆ ${ }^{1}$, Gordana GOJGIĆ-CVIJOVIĆ², SofiJa PAVKOVIĆ-LUČIĆ1 \\ and TATJANA SAVIĆ ${ }^{3}$ \\ 1 University of Belgrade, Faculty of Biology, 16 Studentski trg, 11000 Belgrade, Serbia; e-mails: jelena.trajkovic@bio.bg.ac.rs,
vukica.vujic@bio.bg.ac.rs, draganam@bio.bg.ac.rs, sofija@bio.bg.ac.rs
${ }^{2}$ University of Belgrade, Institute of Chemistry, Technology and Metallurgy, 12 Njegoševa, 11000 Belgrade, Serbia;
e-mail: ggojgic@chem.bg.ac.rs
${ }^{3}$ University of Belgrade, Institute for Biological Research “Siniša Stanković”, 142 Despot Stefan Blvd, 11000 Belgrade, Serbia;
e-mail: tanjat@ibiss.bg.ac.rs
}

Key words. Diptera, Drosophilidae, Drosophila melanogaster, nutrition, fitness components, protein content, C/N ratio

\begin{abstract}
Nutrition is one of the most important environmental factors that influence the development and growth in Drosophila. The food composition strongly affects their reproduction, welfare and survival, so it is necessary for flies to search for a mixture of macronutrients that maximizes their fitness. We have five $D$. melanogaster strains, which were reared for 13 years on five different substrates: standard cornmeal-agar-sugar-yeast medium and four substrates modified by adding tomato, banana, carrot and apple. This study was aimed at determining how such long-term rearing of flies on substrates with different protein content affects fitness traits (dynamics of eclosion, developmental time and egg-to-adult survival). Further, we determined how transferring flies reared on fruit/vegetable substrates to a standard laboratory diet affected their fitness. Results indicate that strains reared on the diet with the lowest content of protein and the highest $\mathrm{C} / \mathrm{N}$ ratio had the slowest eclosion and developmental time, and lowest egg-to-adult survival (apple diet). The flies reared on the diet with the highest protein content and the lowest $\mathrm{C} / \mathrm{N}$ ratio had the highest survival (tomato diet). Flies reared on the carrot diet, which is quite similar in protein content and $\mathrm{C} / \mathrm{N}$ ratio to the standard cornmeal diet, had the fastest development. Transferring flies to the standard cornmeal diet accelerate eclosion and developmental time, but did not affect survival.
\end{abstract}

\section{INTRODUCTION}

Food is essential for the survival of all organisms, as it provides energy for different biological functions. During the course of a lifetime there is a requirement for specific nutrients for optimal body growth. However, in nature animals are often exposed to changes in the quality and quantity of food, and in its availability. Consequently, there are changes in their resistance to stress, life-history traits and reproduction (Djawdan et al., 1998; Bross et al., 2005; Broughton et al., 2005; Carsten et al., 2005; Burger et al., 2007; Sisodia \& Singh, 2012; Reddiex et al., 2013; AbedVieillard et al., 2014; Rodrigues et al., 2015; Kristensen et al., 2016).

D. melanogaster is one of the most frequently used model organisms in a variety of nutritional studies. Consuming food of different qualities is widely evaluated in ethanoltolerance studies (McKechnie \& Geer, 1993), mobility and cardiac physiology (Bazzell et al., 2013), developmental and metabolic studies (Kolss et al., 2009; Matzkin et al., 2011), ageing (Piper \& Partridge, 2007), morphological investigations (Kristensen et al., 2011; Güler et al., 2015) including fluctuating asymmetry studies (Vijendravarma et al., 2011), learning and memory (Kolss \& Kawecki, 2008; Wright, 2011), cuticular chemistry research (Fedina et al., 2012; Pavković-Lučić et al., 2016) and sexual selection studies (Fricke et al., 2008; Abed-Vieilliard \& Cortot, 2016). So far, nutrigenomic studies on D. melanogaster have been used to further our understanding of human nutrigenomics, as metabolism is evolutionarily conserved (Ruden \& Lu, 2006), and a promising way of developing strategies for dealing with metabolic diseases (Matzkin et al., 2011).

Most of the nutritional studies involving D. melanogaster focus on adults, in spite of the fact that larvae could be a better choice for studying this species nutritional requirements (Scherer et al., 2003; Schwarz et al., 2014). Depending on the nutritional composition of the diet, larvae increase in body mass (Sang, 1956, 1978), but are sensitive to the amount of simple sugars and yeast in the diet (Durisko \& Dukas, 2013; Neuser et al., 2005). 
D. melanogaster is a generalist that uses different fruits and vegetables for both feeding and reproduction (Shorrocks, 1972; Markow, 2015). Certain amounts of protein, carbohydrate, lipid, vitamins and minerals are essential for growth and survival of juveniles (Simpson \& Raubenheimer, 1993; Simpson et al., 2004). The amount of protein and carbohydrate in the larval food of $D$. melanogaster affects their developmental time, egg-to-adult survival and lifespan (Chippindale et al., 1998; Heilbronn \& Ravussin, 2005; Fanson et al., 2009; Andersen et al., 2010; Kristensen et al., 2011; Merkey et al., 2011; Rodrigues et al., 2015; Reis, 2016). However, it is only protein that determines body and tissue growth in larvae (Britton \& Edgar, 1998; Colombani et al., 2003). Larval nutrition further affects resistance of adults to heat and cold, starvation and desiccation (Andersen et al., 2010; Kristensen et al., 2016). Effects of nutrition can be sex specific (Lee $\&$ Micchelli, 2013; Reddiex et al., 2013; Nazario-Yepiz et al., 2017). Thus, for females of D. melanogaster the protein to carbohydrate $(\mathrm{P}: \mathrm{C})$ ratio affects longevity, egg laying rate and lifetime egg production (Lee et al., 2008; Fanson et al., 2009; Rodrigues et al., 2015).

To our knowledge, there are insufficient studies on the fitness consequences of long-term culturing of insects (over decades), including D. melanogaster, on diets of different qualities. In most nutritional studies on $D$. melanogaster, the quality of the diet is manipulated by altering the concentrations and ratios of yeast and sugar (Kristensen et al., 2011; Matzkin et al., 2011; Fanson et al., 2012; Güller et al., 2015), or by modifying the food by using different species of yeast (Anagnostou et al., 2010), dietary carbohydrates (Lushchak et al., 2014), lipids, vitamins (Reis, 2016) and food additives (Neethu et al., 2014). However, this study involved using diets that are modifications of this flies' natural food (tomato, banana, carrot and apple), prepared without adding sugar and yeast. Tomatoes are hosts for many insects: D. melanogaster is frequently recorded infesting tomato crops, which in the past resulted in a great deal of damage (De Camargo \& Phaff, 1957; Lange \& Bronson, 1981). One of the most attractive blends for D. melanogaster is produced by banana (Schubert et al., 2014), which was often used as the diet for maintaining cultures of flies and in different experiments (Jaenike, 1983; Demerc \& Kaufman, 1996; Svilpe \& Matjuškova, 2010; Stamps et al., 2012; Chhabra et al., 2013; Ho et al., 2013; Prakash \& Krishna, 2015). Carrot is included in D. melanogaster diets as it is a rich source of carotenoids. It is reported that $D$. melanogaster larvae need large amounts of dietary carotenoids for the biosynthesis of visual pigments (Giovannucci \& Stephenson, 1999). Further, carotenoids influence insect multitrophic interactions and affect the evolutionary outcomes (Heath et al., 2013). Apples are also highly attractive and commonly used for trapping fruit flies, and experiments on habitat selection and life-history traits (Jaenike, 1983; Hoffmann et al., 1984; Hoffmann, 1985; Pavković-Lučić et al., 2012; Kristensen et al., 2016). It is reported that apple polyphenols, which are a rich source of antioxidants, extend the lifespan of $D$. melanogaster (Peng et al., 2011).

Using the aforementioned D. melanogaster strains, we set out to determine (1) the extent to which the long-term rearing of flies on different fruit/vegetable foods affects their fitness traits and (2) whether these traits are affected by transferring eggs to a standard laboratory diet, assuming that plastic adaptation to the new nutritive environment may have fitness consequences.

In nature, D. melanogaster lives, feeds, and breeds in the same place (Reaume \& Sokolowski, 2006), so the ability to adapt to a new diet is important. D. melanogaster can detect the nutritional quality of a particular food and induce an adaptive plastic response (Partridge et al., 2005). Phenotypic plasticity, defined as "the ability of individual genotypes to produce different phenotypes when exposed to different environmental conditions" (Pigliucci et al., 2006) can influence fitness directly, if the ability to be plastic is adaptive (Sultan \& Spencer, 2002; Crispo, 2008; Stomp et al., 2008), or indirectly, if the plastic response results in the development of an adaptive phenotype (Via et al., 1995). During their lifetime, individuals may adapt by means of developmental plasticity, since they may experience environments in early life that are associated with particular conditions they will experience later in life (Monaghan, 2008; Pilakouta et al., 2015). Selection for feeding on different foods can result in trade-offs associated with the adaptation, which could be manifested in terms of larval development and survival (Kolss et al., 2009). If there is a diet-induced developmental plasticity then our strains should differ in their efficiency to utilize the carbohydrates and proteins in the diet. The shift to a standard laboratory food, prepared with yeast and sugar as an important protein and energy sources, could affect their fitness.

\section{MATERIAL AND METHODS}

\section{Chemical analysis of substrates}

Total dry weight of samples of substrate was determined by oven drying to constant weight at $105^{\circ} \mathrm{C}$ to $(6 \mathrm{~h}+2 \mathrm{~h}$, depending on the sample) (Bradley, 2010). For the analysis of carbon (C), hydrogen $(\mathrm{H})$, nitrogen $(\mathrm{N})$ and sulphur $(\mathrm{S})$ content a Vario EL III $\mathrm{CHNS} / \mathrm{O}$ Elemental Analyzer was used. Content of crude protein was calculated from the nitrogen content by multiplying it by the factor 6.25 (AOAC, 1995).

\section{Fly strains and substrates}

D. melanogaster flies were collected from a natural population and reared over 13 years (more than 300 generations) on five different diets, in 20 replicated lines for each diet group. Flies were reared on the standard cornmeal-sugar-agar-yeast diet (St), and four diets modified by adding tomato (T), banana (B), carrot (C) and apple (A) (Fig. 1). Only the standard diet was prepared with additional sugar and yeast, which were not added to the fruit/vegetable diets (Table 1, Kekić \& Pavković-Lučić, 2003). Flies were reared in $250 \mathrm{ml}$ glass bottles filled with $50 \mathrm{ml}$ of food ( 20 bottles per substrate), under standard laboratory conditions (temperature of $\sim 25^{\circ} \mathrm{C}$, relative humidity of $60 \%, 300$ lux of illumination, and 12L: 12D cycle). Large population, of about 2000 individuals per strain, were maintained from generation to generation in density controlled, low competition conditions (about 100 individuals per bottle) in order to reduce genetic drift. 


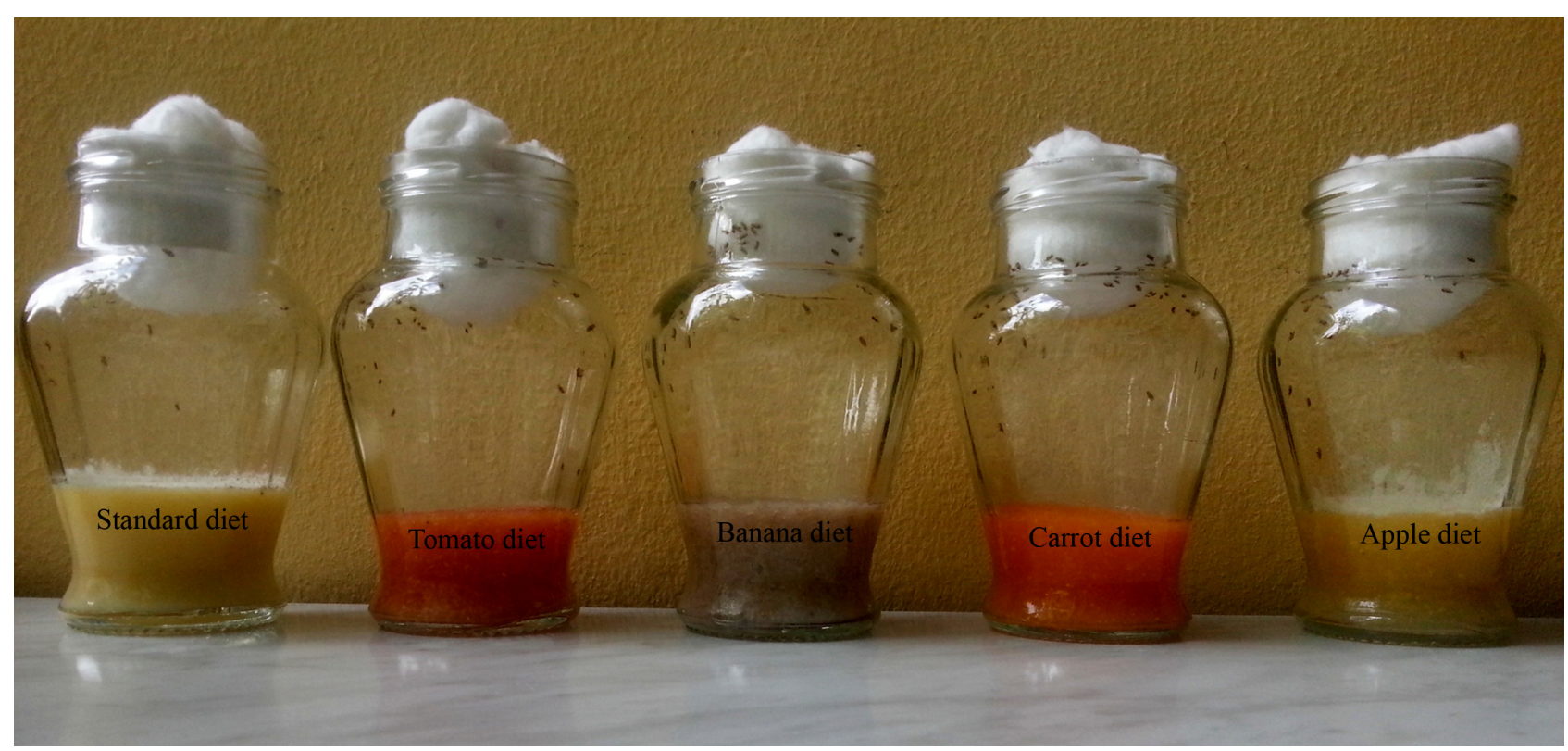

Fig. 1. Bottles containing D. melanogaster flies reared on standard, tomato, banana, carrot and apple diets.

\section{Experimental groups}

Two experimental groups (Fig. 2) were set up and scored for fitness components. In experimental group I, fitness components were scored for flies reared on the diet they had been reared on for 13 years ("native" diet). In experimental group II, flies laid eggs on their native diet, which were then transferred to the St diet, on which their fitness components were determined.

\section{Experimental procedure}

To estimate the fitness components, thirty to fifty 4-5 days old fertilized females were transferred to egg laying vials. They were left to oviposit in $60 \varnothing \mathrm{mm}$ Petri dishes for $12 \mathrm{~h}$. Petri dishes were filled with the native substrate for every strain. Eggs were collected and transferred in groups of 60 to new vials filled with 30 $\mathrm{ml}$ of the native diet for every strain (for experimental group I) or filled with $30 \mathrm{ml}$ of standard diet (for experimental group II). There were 5-7 replicates per strain and per experimental group. The number of flies that emerged was counted daily until no further flies emerged.

\section{Assessment of fitness components}

We measured the following fitness components: dynamics of eclosion, developmental time, and egg-to-adult survival. Dynamics of eclosion is the percentage of flies the emerged per day. Developmental time (Dt) was calculated as the average time weighted by the number of adults that emerged. It was determined using the following formula: $\mathrm{Dt}=\left(\Sigma n_{d} \times d\right) / \Sigma n_{d}$, where $n_{d}$ is the num-

Table 1. Composition of the five diets used for long-term culturing of $D$. melanogaster strains (according to Kekić \& Pavković-Lučić, 2003). Abbreviations: N - Nipagin, E - ethanol.

\begin{tabular}{lccc}
\hline Ingredients & $\begin{array}{c}\text { Standard } \\
\text { diet }\end{array}$ & $\begin{array}{c}\text { Tomato } \\
\text { diet }\end{array}$ & $\begin{array}{c}\text { Banana, Carrot, } \\
\text { Apple diets }\end{array}$ \\
\hline Distilled water & $1100 \mathrm{ml}$ & $200 \mathrm{ml}$ & $680 \mathrm{ml}$ \\
Quantity of fruits/vegetables & $/$ & $900 \mathrm{~g}$ & $600 \mathrm{~g}$ \\
Cornmeal & $104 \mathrm{~g}$ & $60 \mathrm{~g}$ & $20 \mathrm{~g}$ \\
Sugar & $94 \mathrm{~g}$ & $/$ & $/$ \\
Yeast & $20 \mathrm{~g}$ & $/$ & $/$ \\
Agar & $7 \mathrm{~g}$ & $12 \mathrm{~g}$ & $10 \mathrm{~g}$ \\
Fungicide & $2.5 \mathrm{~g} \mathrm{~N} /$ & $2 \mathrm{~g} \mathrm{~N} /$ & $2 \mathrm{~g} \mathrm{~N} /$ \\
& $30 \mathrm{ml} \mathrm{E}$ & $20 \mathrm{ml} \mathrm{E}$ & $20 \mathrm{ml} \mathrm{E}$ \\
\hline
\end{tabular}

${ }^{*}$ Amount is sufficient for $20(250 \mathrm{ml})$ glass bottles. ber of adults that emerged per each day, and $d$ is day of hatching. Since there were no differences between the replicates the results for each strain were pooled. Egg-to-adult survival was expressed as the ratio of the number of flies that emerged and the number of eggs placed in a vial.

\section{Statistical analysis}

The assumption of normality of variances and homoscedasticity was confirmed using Kolmogorov-Smirnov and Levene's tests for both developmental time and survival. One-Way ANOVA was used to analyse developmental time and egg-to-adult survival, depending on the diets. Mean developmental time and mean egg-toadult survival were calculated for each vial, and these values were used as "units" in ANOVA. Further, a Post hoc Fisher's LSD test was used. Spearman's rank test was used to analyse correlations between protein content and developmental time and egg-to-adult survival. All statistical analyses were performed in STATISTI$\mathrm{CA}^{\circledR}$, ver. 5.0 (StatSoft).

\section{RESULTS}

\section{Chemical analysis of substrates}

Percentage of nitrogen $(\mathrm{N})$, carbon $(\mathrm{C})$, hydrogen $(\mathrm{H})$ and sulphur (S) in the five diets are presented in Table 2. Considering the nature of these diets, the expected amount of lipid in these substrates is unlikely to exceed a few percent (USDA Food Composition Databases). $\mathrm{C} / \mathrm{N}$ ratio indicates the proportion of protein relative to the total content of organic carbon, which in this case accurately reflects

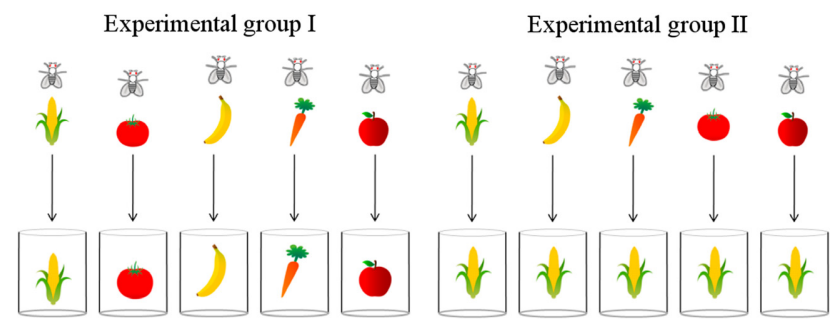

Fig. 2. Scheme of the experimental design. 
a)

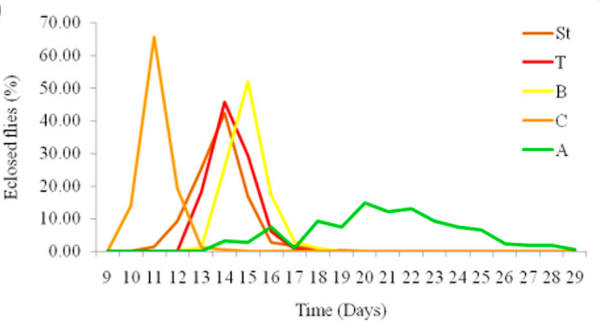

b)

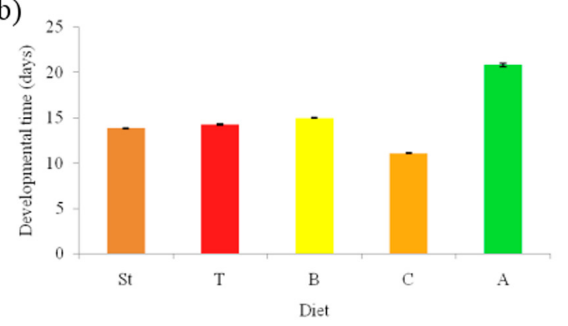

c)

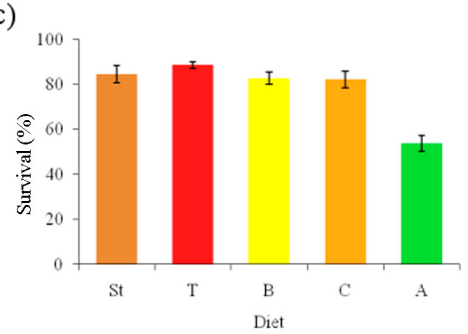

Fig. 3. Dynamics of eclosion (a), developmental time (b) and egg-to-adult survival (c) of $D$. melanogaster strains reared on five different diets for 13 years.

the protein: carbohydrate $(\mathrm{P}: \mathrm{C})$ ratio. Protein content was highest in the tomato diet and lowest in the apple diet. Consequently, the $\mathrm{C} / \mathrm{N}$ ratio was the highest in the apple diet, and the lowest in the tomato diet (Table 2).

\section{Experimental group I}

\section{Dynamics of eclosion and developmental time}

Dynamics of eclosion and mean developmental time ( \pm S.E.) of flies reared on their native diets are presented in Fig. 3a and b, respectively. St flies emerged from the $11^{\text {th }}$ to $19^{\text {th }}$ day, with the largest number emerging on day 14 . Their mean developmental time was $13.82 \pm 0.07$ days. Eclosion of both $\mathrm{T}$ and $\mathrm{B}$ flies started on the $13^{\text {th }}$ day and that of $\mathrm{T}$ flies ended on the $17^{\text {th }}$ day and of $B$ flies on the $18^{\text {th }}$ day. The largest number of T flies emerged on day 14 and of B flies on day 15 . For the $\mathrm{T}$ and $\mathrm{B}$ flies development lasted, on average, $14.25 \pm 0.05$ and $14.97 \pm 0.05$ days, respectively. Eclosion of $\mathrm{C}$ flies started on day 10 and ceased on day 14 . The highest percentage of adults of $\mathrm{C}$ strain emerged on the $11^{\text {th }}$ day, and mean developmental time was $11.08 \pm 0.04$ days. On the other hand, A flies started emerging on day 14 and the last emerged on day 29, and the largest number of flies emerged on day 20. Mean developmental time of A flies was $20.82 \pm 0.22$ days. One-Way ANOVA indicates that the strains significantly differed in developmental time $(\mathrm{F}=66.240, \mathrm{df}=4$, error $\mathrm{df}=25, \mathrm{p}<0.001)$. Post hoc LSD test revealed that $\mathrm{C}$ flies developed the fastest $(\mathrm{p}<0.001)$ and A flies the slowest $(p<0.001)$. Spearman's rank test revealed no significant correlations between developmental time and protein content $\left(r_{\mathrm{s}}=-0.600, \mathrm{p}>0.05\right)$.

\section{Egg-to-adult survival}

Mean egg-to-adult survival ( \pm S.E.) in Experimental group I is presented in Fig. 3c. One-Way ANOVA revealed significant difference in egg-to-adult survival among strains $(\mathrm{F}=22.342, \mathrm{df}=4$, error $\mathrm{df}=25, \mathrm{p}<0.001)$. LSD Post hoc analysis indicates that the egg-to-adult survival of $\mathrm{T}$ flies was the highest $(88.61 \% \pm 1.41 ; \mathrm{p}<0.001)$ and

Table 2. Content of macronutrients $(g / 100 \mathrm{~g}$ of dry matter of substrate). Abbreviations: $\mathrm{N}$ - Nitrogen, $\mathrm{C}-$ Carbon, $\mathrm{H}-$ Hydrogen, $S-$ Sulphur.

\begin{tabular}{lcccccc}
\hline Diet & $\mathrm{N} \%$ & $\mathrm{C} \%$ & $\mathrm{H} \%$ & $\mathrm{~S} \%$ & $\begin{array}{c}\text { Crude protein } \\
\%, \mathrm{~N} \times 6.25\end{array}$ & $\begin{array}{c}\mathrm{C} / \mathrm{N} \\
\text { ratio }\end{array}$ \\
\hline Standard diet & 1.29 & 42.41 & 6.35 & 0.65 & 8.06 & 32.87 \\
Tomato diet & 2.21 & 46.30 & 6.48 & 0.53 & 13.81 & 20.95 \\
Banana diet & 0.72 & 42.61 & 6.00 & 0.50 & 4.47 & 59.59 \\
Carrot diet & 1.22 & 41.91 & 5.92 & 0.48 & 7.63 & 34.35 \\
Apple diet & 0.25 & 41.34 & 5.94 & 0.44 & 1.53 & 168.73 \\
\hline
\end{tabular}

that of A flies the lowest $(53.71 \% \pm 3.48 ; \mathrm{p}<0.001)$. The egg-to-adult viabilities of St, B and C flies were $84.44 \% \pm$ $3.82,82.67 \% \pm 2.70$ and $82.22 \% \pm 3.71$, respectively. The Spearmen's rank coefficient revealed a significant correlation between protein content and egg-to-adult survival $\left(r_{\mathrm{s}}\right.$ $=0.900, \mathrm{p}<0.05)$.

\section{Experimental group II}

\section{Dynamics of eclosion and developmental time}

Dynamics of eclosion and mean developmental time $( \pm$ S.E.) in Experimental group II is presented in Fig. 4a and $b$, respectively. After transferring to the St diet, flies of all strains started to emerge on day 10, except T-to-St flies, which started on day 12. The largest number of flies emerged on days 12 and 13. The duration of emergence varied among diets: that of C-to-St flies lasted 14 days and of A-to-St flies 20 days. One-Way ANOVA detected significant difference in developmental time among flies transferred from their native to the $\mathrm{St} \operatorname{diet}(\mathrm{F}=3.734, \mathrm{df}=$ 4 , error $\mathrm{df}=20, \mathrm{p}<0.05)$. LSD test revealed that both the C-to-St flies (in days: $11.94 \pm 0.06 ; \mathrm{p}<0.01$ ) and B-to-St flies (in days: $11.61 \pm 0.08 ; \mathrm{p}<0.01$ ) developed significantly faster than the St flies (in days: $13.82 \pm 0.07$; $<$ 0.01 ) and B-to-St flies than the A-to-St flies (in days: 12.64 $\pm 0.11 ; \mathrm{p}<0.05)$. Mean developmental time of T-to-St flies was $12.83 \pm 0.07$ days.

\section{Egg-to-adult survival}

Mean egg-to-adult survival ( \pm S.E.) of strains reared on fruit and vegetable diets and transferred to the St diet is presented in Fig. 4c. One-Way ANOVA confirmed significant differences in egg-to-adult survival among the strains transferred to the St diet $(\mathrm{F}=4.082$, $\mathrm{df}=4$, error $\mathrm{df}=20$, $\mathrm{p}<0.05)$. LSD test indicated that the egg-to-adult survival of A-to-St flies $(65.15 \% \pm 5.52)$ was significantly lower than that of the C-to-St flies $(84.17 \% \pm 3.22, \mathrm{p}<0.05)$, Tto-St flies $(86.94 \% \pm 0.96, \mathrm{p}<0.01)$ and St flies $(84.44 \% \pm$ $3.82, \mathrm{p}<0.01)$. Egg-to-adult survival of B-to-St flies was $79.17 \% \pm 7.77$.

\section{Experimental group I vs. Experimental group II}

Dynamics of eclosion and developmental time

The beginning of hatching and the largest number of $\mathrm{T}$ flies emerging was recorded 1 day earlier, when $\mathrm{T}$ flies were transferred to the St diet. Also, the hatching of B flies started 2 days earlier and the largest number of flies emerged 3 days earlier on the St diet than on their native diet. The largest change in dynamics of eclosion was re- 

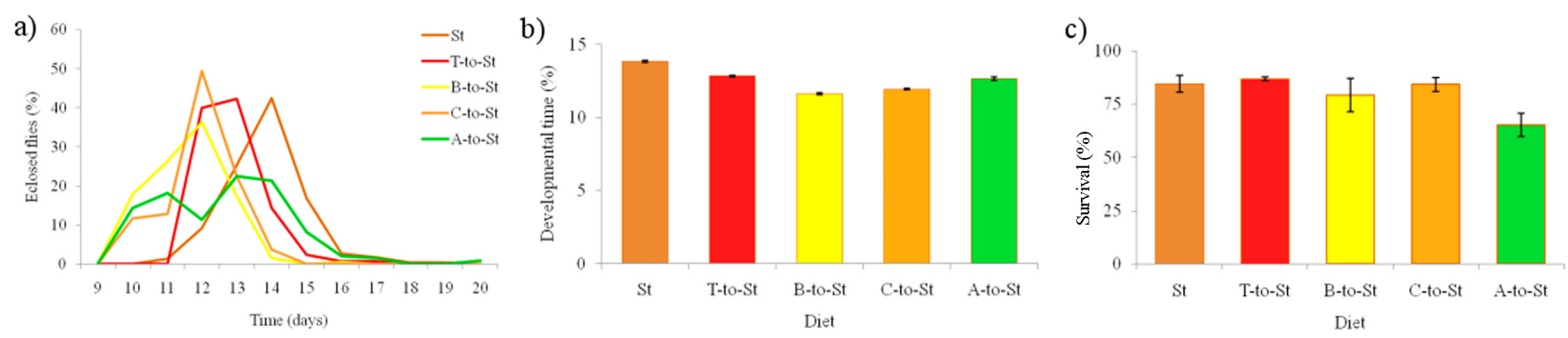

Fig. 4. Dynamics of eclosion (a), developmental time (b) and egg-to-adult survival (c) of $D$. melanogaster strains reared on different diets for 13 years, after transfer to the standard diet.

corded for A flies. Emergence of A flies started 4 days earlier and ended 9 days earlier on the St diet than on their native diet. Further, the largest number of flies emerged 7 days earlier on the St diet. Flies of T, B and A strains developed significantly faster on the St diet than on their native diets ( $\mathrm{T}$ strain: $\mathrm{F}=10.48, \mathrm{df}=1$, error $\mathrm{df}=7, \mathrm{p}<$ 0.05; B strain: $F=65.099$, error $\mathrm{df}=7, \mathrm{df}=1, \mathrm{p}<0.001$; A strain: $\mathrm{F}=66.030, \mathrm{df}=1$, error $\mathrm{df}=12, \mathrm{p}<0.001)$. On the other hand, dynamics of eclosion of $\mathrm{C}$ flies remained the same on the St and $\mathrm{C}$ diets, while the largest number of flies emerged 1 day earlier on the St diet. Based on the One-Way ANOVA, there was no difference in the developmental times $\mathrm{C}$ flies reared on their native diet and the $\mathrm{St}$ $\operatorname{diet}(\mathrm{F}=5.06, \mathrm{df}=1$, error $\mathrm{df}=9, \mathrm{p}>0.05)$.

\section{Egg-to-adult survival}

Egg-to-adult survival of flies transferred to the St diet did not differ significantly from that recorded on their native diets ( $\mathrm{T}$ flies: $\mathrm{F}=0.1390, \mathrm{df}=1$, error $\mathrm{df}=7, \mathrm{p}>0.05$; $\mathrm{B}$ flies: $\mathrm{F}=0.1904, \mathrm{df}=1$, error $\mathrm{df}=7, \mathrm{p}>0.05 ; \mathrm{C}$ flies: $\mathrm{F}=$ $0.328, \mathrm{df}=1$, error $\mathrm{df}=9, \mathrm{p}>0.05$; A flies: $\mathrm{F}=3.1634$, $\mathrm{df}$ $=1$, error $\mathrm{df}=12, \mathrm{p}>0.05)$.

\section{DISCUSSION}

Diet affects many biological processes, starting from cellular metabolism up to behaviour. Quality and amount of nutritive resources, as well as the balance of macronutrients in food, have a strong effect on the life-history traits of D. melanogaster (Lee et al., 2008; Kolss et al., 2009; Kristensen et al., 2011; Schwarz et al., 2014; May et al., 2015; Rodrigues et al., 2015; Simpson et al., 2015; AbedVieillard \& Cortot, 2016). Nutritive demands may change during the course of life and may be sex-specific, if the sexes maximize fitness in different ways (Lee et al., 2008; Maklakov et al., 2008; Lihoreau et al., 2016).

D. melanogaster larvae feed and live on rotting fruit, acquiring most of their protein from the yeasts present on fruit when it is decomposing (Begon, 1982). It is recorded that $D$. melanogaster reared on a protein rich diet are more viable, heavier and larger, and have more ovarioles (Rodrigues et al., 2015). On the other hand, a low level of protein in the diet results in prolonged development, delay in emergence and decrease in egg-to-adult survival, fecundity and growth in D. melanogaster (Wang \& Clark, 1995; Tu \& Tatar, 2003; Kolss et al., 2009; Rodrigues et al., 2015). Results obtained in this study confirm the results of the above mentioned studies. The strain reared on the diet with the highest percentage of protein, and the lowest $\mathrm{C} / \mathrm{N}$ ratio (tomato diet, $\mathrm{C} / \mathrm{N}$ ratio $=20.95$ ), had the highest egg-to-adult survival. On the diet with the lowest percentage of protein and highest $\mathrm{C} / \mathrm{N}$ ratio (apple diet, $\mathrm{C} / \mathrm{N}$ ratio $=168.73$ ) the emergence of adults was delayed and development prolonged, and the lowest egg-to-adult survival recorded. However, the banana diet also has a high $\mathrm{C} / \mathrm{N}$ ratio $(\mathrm{C} / \mathrm{N}$ ratio $=59.59)$, but the fitness components did not differ significantly from those recorded for the strain reared on the standard diet, or on the tomato diet (which had the smallest $\mathrm{C} / \mathrm{N}$ ratio). As eggs and larvae are more sessile than adult flies, it is expected that their oviposition behaviour and selection of pupation sites has been strongly selected for (Markow, 2015). However, Jaenike (1983), reports that females lay more eggs on apple than on tomato, although our study indicates that the apple diet had "the lowest" quality in terms of both larval development and egg-to-adult survival. In nature, a prolonged developmental time increases the risk of running out of food and not completing their development. In such condition, selection against very slow development may be strong. Thus, relatively fast larval development in nature is an important aspect of the adaptation to larval nutrition (Kolss et al., 2009).

D. melanogaster larvae have a natural propensity to balance their diet. Flies fed on a diet deficient in proteins or carbohydrates later preferred the diet containing the nutrients they required. Also, when larvae are offered a choice between a balanced, protein rich or carbohydrate rich diets, they chose the balanced diet (Schwarz et al., 2014). Recently, Rodrigues et al. (2015) report that the shortest developmental time is recorded for flies fed on a diet with an intermediate $\mathrm{P}: \mathrm{C}$ ratio (ratio of about $1: 2-1: 4$ ). Also, egg-laying rate and lifetime egg production is maximized when fed on diets with a $\mathrm{P}: \mathrm{C}$ ratio $1: 2$ and $1: 4$, respectively (Lee et al., 2008). Krijger et al. (2001) report that among neotropical Drosophila species, those with a short development had a competitive advantage over those with a long development. In our study, flies reared on the carrot diet had a shorter development and dynamics of eclosion than the other four strains. Although the carrot diet and standard diet did not differ in protein content and $\mathrm{C} / \mathrm{N}$ ratio (carrot diet, $\mathrm{C} / \mathrm{N}$ ratio $=34.35$; standard diet, $\mathrm{C} / \mathrm{N}$ ratio $=$ 32.87), it is possible that these two diets may differ in the quality of the protein (i.e., in amino acid composition). 
The standard cornmeal-sugar-agar-yeast medium is commonly used for maintaining cultures of $D$. melanogaster flies under laboratory conditions. In that sense, fitness components of the flies reared on the standard diet could be the control for all other diets (Kolss et al., 2009). Changes in fitness components after transferring eggs from their native fruit/vegetable diets to the standard diet could be the result of plastic responses to the different nutrition. After transferring eggs to the standard diet, the developmental time of almost all the strains changed, but egg-to-adult survival was not affected. Thus, it is possible that regulation of the developmental time buffered survival, because the developmental time was not correlated with protein content, while egg-to-adult survival was.

D. melanogaster has a genetic potential to adapt to different nutritional conditions based on transcriptional dynamics (Kolss et al., 2009; Whitaker et al., 2014). Developmental plasticity provides developing individuals with multiple phenotypes each expressed under different nutritional regimes (Xie et al., 2015). This is an adaptive process, which may result in changes manifested at physiological, morphological and behavioural levels (Monaghan, 2008; Kolss et al., 2009; Shingleton et al., 2009; Beldade et al., 2011; Kristensen et al., 2011; Trajković et al., 2013; Güller et al., 2015; Rodrigues et al., 2015). Phenotypic plasticity might allow individuals to "jump" from one fitness peak to another, without crossing fitness valleys (Price et al., 2003; Crispo, 2007). This study reveals that such a scenario is possible in just one generation.

Results of this study demonstrate that different fitness components do not respond similarly to the different protein compositions and $\mathrm{C} / \mathrm{N}$ ratios of the larval diet, and indicate a plastic response when D. melanogaster is exposed to different nutritional environments. In that sense, differences in fitness traits recorded in the strains used is a challenge for future studies, which could include establishing relationships with morphological characteristics (e.g. body size), physiological properties (e.g. tolerance of stress) and different behavioural traits. Adaptive significance of phenotypic plasticity, possible trade-offs between larval and adult traits, as well as underlying molecular mechanisms should also be further investigated.

ACKNOWLEDGMENTS. This work was funded by The Serbian Ministry of Education, Science and Technological Development (Grant No. 173012). We would also like to thank to L. Filipović for laboratory assistance. The clarity of this article was greatly improved by constructive and useful comments from two anonymous reviewers.

\section{REFERENCES}

Abed-Vieillard D. \& Cortot J. 2016: When choice makes sense: Menthol influence on mating, oviposition and fecundity in Drosophila melanogaster. - Front. Integr. Neurosci. 10: 5, 11 pp.

Abed-Vieillard D., Cortot J., Everaerts C. \& Ferveur J.-F. 2014: Choice alters Drosophila oviposition site preference on menthol. - Biol. Open 3: 22-28.

Anagnostou C., LeGrand E.A. \& Rohlfs M. 2010: Friendly food for fitter flies? Influence of dietary microbial species on food choice and parasitoid resistance in Drosophila. _ Oikos 119: 533-541.

Andersen L.H., Kristensen T.N., Loeschcke V., Toft S. \& MAYNTZ D. 2010: Protein and carbohydrate composition of larval food affect tolerance to thermal stress and desiccation in adult Drosophila melanogaster. - J. Insect Physiol. 56: 336-340.

AOAC 1995: Official Methods of Analysis of AOAC International, 16th ed. Association of Official Analytical Chemists (AOAC), Gaithersburg, MD, USA.

Bazzell B., Ginzberg S., Healy L. \& Wessells R.J. 2013: Dietary composition regulates Drosophila mobility and cardiac physiology. - J. Exp. Biol. 21: 859-868.

BEGOn M. 1982: Yeast and Drosophila. In Ashburner M., Carson H.L. \& Thompson J.N. Jr. (eds): The Genetics and Biology of Drosophila. 3b. Academic Press, London, pp. 345-384.

Beldade P., Mateus A.R. \& Keller R.A. 2011: Evolution and molecular mechanisms of adaptive developmental plasticity. - Mol. Ecol. 20: 1347-1363.

BRADLEY R.L. JR. 2010: Moisture and total solids analysis in food analysis. In Nielsen S.S. (ed.): Food Analysis, 4th ed. Springer Science + Business Media, New York, pp. 88-91.

Britton J.S. \& EDGAR B.A. 1998: Environmental control of the cell cycle in Drosophila: nutrition activates mitotic and endoreplicative cells by distinct mechanisms. - Development 125: 2149-2158.

Bross T.G., Rogina B. \& Helfand S.L. 2005: Behavioral, physical, and demographic changes in Drosophila populations through dietary restriction. - Aging Cell 4: 309-317.

Broughton S.J., Piper M.D., Ikeya T.M., Jacobson J., Driege Y., Martinez P., Hafen E., Withers D.J., Leevers S.J. \& Partridge L. 2005: Longer lifespan, altered metabolism, and stress resistance in Drosophila from ablation of cells making insulin-like ligands. - Proc. Nat. Acad. Sci. USA 102: 3105-3110.

Burger J.M., Hwangbo D.S., Corby-HarrisV. \& Promislow D.E. 2007: The functional costs and benefits of dietary restriction in Drosophila. - Aging Cell 6: 63-71.

Carsten L.D., Watts T. \& Markow T.A. 2005: Gene expression patterns accompanying a dietary shift in Drosophila melanogaster. - Mol. Ecol. 14: 3203-3208.

Chippindale A.K., Gibbs A.G., Sheik M., Yee K.J., Duwadan M., Bradley T.J. \& Rose M.R. 1998: Resource acquisition and the evolution of stress resistance in Drosophila melanogaster. Evolution 52: 1342-1352.

ChHabra R., Kolli S. \& Bauer J.H. 2013: Organically grown food provides health benefits to Drosophila melanogaster. PLOS ONE 8: e52988, 8 pp.

Colombani J., Raisin S., Pantalacci S., Radimerski T., Montagne J. \& Leopold P. 2003: A nutrient sensor mechanism controls Drosophila growth. - Cell 114: 739-749.

CRISPO E. 2007: The Baldwin effect and genetic assimilation: revisiting two mechanisms of evolutionary change mediated by phenotypic plasticity. - Evolution 61: 2469-2479.

CRISPO E. 2008: Modifying effects of phenotypic plasticity on interactions among natural selection, adaptation and gene flow. - J. Evol. Biol. 21: 1460-1469.

De Camargo R. \& Phaff H.J. 1957: Yeasts occurring in Drosophila flies and in fermenting tomato fruits in Northern California. - J. Food Sci. 22: 367-372.

Demerc M. \& Kaufman B.P. 1996: Drosophila Guide. Carnegie Institution, Washington, $46 \mathrm{pp}$.

Djawdan M., Chippindale A.K., Rose M.R. \& Bradley T.J. 1998: Metabolic reserves and evolved stress resistance in Drosophila melanogaster. — Physiol. Zool. 71: 584-594. 
Durisko Z. \& Dukas R. 2013: Attraction to and learning from social cues in fruit fly larvae. - Proc. R. Soc. (B) 280: 20131398, $7 \mathrm{pp}$.

Fanson B.G., Weldon C.W., Pérez-Staples D., Simpson S.J. \& TAYLOR P.W. 2009: Nutrients, not caloric restriction, extend lifespan in Queensland fruit flies (Bactroceratryoni). - Aging Cell 8: 514-523.

FAnson B.G., YAP S. \& TAYLOR P.W. 2012: Geometry of compensatory feeding and water consumption in Drosophila melanogaster. - J. Exp. Biol. 215: 766-773.

Fedina T.Y., Kuo T.H., Dreisewerd K., Dierick H.A., Yew J.Y. \& Pletcher S.D. 2012: Dietary effects on cuticular hydrocarbons and sexual attractiveness in Drosophila. - PLOS ONE 7: e49799, $11 \mathrm{pp}$.

Fricke C., Bretman A. \& Chapman T. 2008: Adult male nutrition and reproductive success in Drosophila melanogaster. - Evolution 62: 3170-3177.

Giovannucci D.R. \& StePHENSON R.S. 1999: Identification and distribution of dietary precursors of the Drosophila visual pigment chromophore: analysis of carotenoids in wild type and ninaD mutants by HPLC. - Vision Res. 39: 219-229.

Güler P., Ayhan N., Koşukcu C. \& Önder B.Ş. 2015: The effects of larval diet restriction on developmental time, preadult survival, and wing length in Drosophila melanogaster. — Turk. J. Zool. 39: 395-403.

Heath J.J., Cipollini D.F. \& Stireman J.O. 2013: The role of carotenoids and their derivatives in mediating interactions between insects and their environment. - Arthr. Plant Interact. 7: $1-20$.

HeILBRonn L.K. \& Ravussin E. 2005: Calorie restriction extends life span - but which calories? - PLoS Med. 2(8): e231, 3 pp.

Ho T., Rejto D., Siu E. \& Sorathia S. 2013: Effects of nutrients from bananas on maturation time of Drosophila melanogaster: preference of Drosophila melanogaster for bananas from different sources. - Expedition 3: 17 pp.

Hoffmann A.A. 1985: Effects of experience on oviposition and attraction in Drosophila: comparing apples and oranges. Am. Nat. 126: 41-51.

Hoffmann A.A., Parsons P.A. \& Nielsen K.M. 1984: Habitat selection: olfactory response of Drosophila melanogaster depends on resources. - Heredity 53: 139-143.

JAENIKE J. 1983: Induction of host preference in Drosophila melanogaster. - Oecologia 58: 320-325.

Kekić V. \& Pavković-Lučíc S. 2003: Fruit and vegetable food media suitable for maintaining D. melanogaster flies. - Drosoph. Inf. Serv. 86: 147.

Kolss M. \& KAWECKI T.J. 2008: Reduced learning ability as a consequence of evolutionary adaptation to nutritional stress in Drosophila melanogaster. - Ecol. Entomol. 33: 583-588.

Kolss M., Vijendravarma R.K., Schwaller G. \& Kawecki T.J. 2009: Life-history consequences of adaptation to larval nutritional stress in Drosophila. - Evolution 63: 2389-2401.

Krijger C.L., Peters Y.C. \& Sevenster J.G. 2001: Competitive ability of neotropical Drosophila predicted from larval development times. - Oikos 92: 325-332.

Kristensen T.N., OvergaArd J., LoeschKe V. \& Mayntz D. 2011 Dietary protein content affects evolution for body size, body fat and viability in Drosophila melanogaster. - Biol. Lett. 7: 269-272.

Kristensen T.N., Henningsen A.K., Aastrup C., Bech-Hansen M., Hoberg Bjerre L.B., Carlsen B., Hagstrup M., Graarup Jensen S., Karlsen P., Kristensen L. et al. 2016: Fitness components of Drosophila melanogaster developed on a standard laboratory diet or a typical natural food source. - Insect Sci. 23: $771-779$
LANGE W.H. \& Bronson L. 1981: Insect pests of tomatoes. Annu. Rev. Entomol. 26: 345-371.

LeE W.-C. \& Micchelli C.A. 2013: Development and characterization of a chemically defined food for Drosophila. - PLoS ONE 8(7): e67308, 10 pp.

Lee K.P., Simpson S.J., Clissold F.J., Brooks R., Ballard J.W.O., Taylor P.W., Soran N. \& Raubenheimer D. 2008: Lifespan and reproduction in Drosophila: New insights from nutritional geometry. - Proc. Natl. Acad. Sci. USA 105: 2498-2503.

Lihoreau M., Poissonnier L.-A., Isabel G. \& Dussutour A. 2016: Drosophila females trade off good nutrition with highquality oviposition sites when choosing foods. - J. Exp. Biol. 219: 2514-2524.

LushchaK O.V., Gospodaryov D.V., RovenKo B.M., YuRKevych I.S., Perkhulyn N.V. \& Lushchak V.I. 2014: Specific dietary carbohydrates differentially influence the life span and fecundity of D. melanogaster. - Gerontol. (A, Biol. Sci. Med. Sci.) 69: 3-12.

Maklakov A.A., Simpson S.J., Zajitschek F., Hall M.D., Dessmann J., Clissold F., Raubenheimer D., Bonduriansky R. \& BROOKS R.C. 2008: Sex-specific fitness effects of nutrient intake on reproduction and lifespan. - Curr. Biol. 18: 10621066.

MARKow T.A. 2015: The secret lives of Drosophila flies. - eLife 4: e06793, 9 pp.

Matzkin L.M., Johnson S., Paight C., Bozinovic G. \& Markow T.A. 2011: Dietary protein and sugar differentially affect development and metabolic pools in ecologically diverse Drosophila. - J. Nutr. 141: 1127-1133.

May C.M., Doroszuk A. \& ZwaAn B.J. 2015: The effect of developmental nutrition on life span and fecundity depends on the adult reproductive environment in Drosophila melanogaster. - Ecol. Evol. 5: 1156-1168.

McKechnie S.W. \& Geer B.W. 1993: Long-chain dietary fatty acids affect capacity of Drosophila melanogaster to tolerate ethanol. - J. Nutr. 123: 106-116.

Merkey A.B., Wong C.K., Hoshizaki D.K. \& Gibbs A.G. 2011: Energetics of metamorphosis in Drosophila melanogaster. J. Insect Physiol. 57: 1437-1445.

Meshrif W.S. \& ElKholy S.E. 2015: Genotype and environment shape the fitness of Drosophila melanogaster. - J. Basic Appl. Zool. 68: 1-9.

Monaghan P. 2008: Early growth conditions, phenotypic development and environmental change. - Phil. Trans. R. Soc. Lond. (B) 363: 1635-1645.

NaZARio-Yapiz N.O., Ramirez Loustalot-Laclette M. \& Markow T.A. 2017: Drosophila species as models for nutritional studies: Development, metabolic pools on diets with contrasting relative sugar: protein ratios. $-J$. Nutr. Biol. 1: 101-107.

Neethu B.K., Babu Y.R. \& Harini B.P. 2014: Flavors supplemented in diet regulate the hatchability and viability in Drosophila. - Drosoph. Inf. Serv. 97: 24-28.

Neuser K., Husse J., Stock P. \& Gerber B. 2005: Appetitive olfactory learning in Drosophila larvae: effects of repetition, reward strength, age, gender, assay type and memory span. Anim. Behav. 69: 891-898

Pavković-Lučić S., Savić T., Jelić M., Kenig B., Tanasković M., Stamenković-Radak M. \& AnĐelković M. 2012: Note on the fauna of Drosophila (Diptera: Drosophilidae) and the first record of Opomyza florum (Diptera: Opomyzidae) from Mountain Goč, Serbia. - Acta Entomol. Serb. 17: 45-53.

Pavković-Lučić S., Todosijević M., Savić T., Vajs V., Trajković J., AnĐelković B., Lučić L., Krstić G., Makarov S., Tomić V. ET AL. 2016: "Does my diet affect my perfume?" Identification 
and quantification of cuticular compounds in five Drosophila melanogaster strains maintained over 300 generations on different diets. - Chem. Biodivers. 13: 224-232.

PARTRIDGe L., PIPER M.D.W. \& MAIR W. 2005: Dietary restriction in Drosophila. - Mech. Ageing Dev. 126: 938-950.

Peng C., Chan H.Y.E., Huang Y., Yu H. \& Chen Z.-Y. 2011: Apple polyphenols extend the mean lifespan of Drosophila melanogaster. - J. Agric. Food Chem. 59: 2097-2106.

Pigliucci M., Murren C.J. \& Schlichting C.D. 2006: Phenotypic plasticity and evolution by genetic assimilation. - J. Exp. Biol. 209: 2362-2367.

Pilakouta N., Jamieson S., Moorad J.A. \& Smiseth P.T. 2015: Parental care buffers against inbreeding depression in burying beetles. - Proc. Natl. Acad. Sci. USA 112: 8031-8035.

Piper M.D. \& PARTRIDge L. 2007: Dietary restriction in Drosophila: delayed aging or experimental artefact? - PLoS Genet. 3(4): e57, 6 pp.

PraKash V.S. \& KRISHNA M.S. 2015: Effect of organic fruits (banana and papaya) on locomotor ability and resistance to eitherizatoin in Drosophila melanogaster. - Int. J. Recent Sci. Res. 6: 4656-4660.

Price T.D., Qvarnström A. \& Irwin D.E. 2003: The role of phenotypic plasticity in driving genetic evolution. - Proc. R. Soc. Lond. (B) 270: 1433-1440.

Reaume C.J. \& Sokolowski M.B. 2006: The nature of Drosophila melanogaster. - Curr. Biol. 16: R623-R638.

Reddiex A.J., Gosden T.P., Bonduriansky R. \& Chenoweth S.F. 2013: Sex-specific fitness consequences of nutrient intake and the evolvability of diet preferences. - Am. Natur. 182: 91-102.

ReIS T. 2016: Effects of synthetic diets enriched in specific nutrients on Drosophila development, body fat, and lifespan. PLoS ONE 11(1): e0146758, 12 pp.

Rodrigues M.A., Martins N.E., Balance L.F., Broom L.N., Dias A.J.S., Fernandes A.S.D., Rodrigues F., Sucena E. \& Mirth C.K. 2015: Drosophila melanogaster larvae make nutritional choices that minimize developmental time. - J. Insect Physiol. 81: 69-80.

Ruden D.M. \& Lu X. 2006: Evolutionary conservation of metabolism explains how Drosophila nutrigenomics can help us understand human nutrigenomics. - Genes Nutr. 1: 75-83.

SANG J.H. 1956: The quantitative nutritional requirements of Drosophila melanogaster. - J. Exp. Biol. 33: 45-72.

SANG J.H. 1978: The nutritional requirements of Drosophila. In Ashburner M. \& Wright T.R.F. (eds): The Genetics and Biology of Drosophila. Vol. 2b. Academic Press, London, pp. 159-192.

Scherer S., Stocker R.F. \& Gerber B. 2003: Olfactory learning in individually assayed Drosophila larvae. - Learn. Mem. 10: 217-225.

Schubert M., Hansson B.S. \& Sachse S. 2014: The banana code - natural blend processing in the olfactory circuitry of Drosophila melanogaster. - Front. Physiol. 5(59): 13 pp.

Schwarz S., Durisko Z. \& Dukas R. 2014: Food selection in larval fruit flies: dynamics and effects on larval development. Naturwissenschaften 101: 61-68.

Shingleton A.W., Estep C.M., Driscol M.V. \& Dworkin I. 2009: Many ways to be small: different environmental regulators of size generate distinct scaling relationships in Drosophila melanogaster. - Proc. R. Soc. Lond. (B) 276: 2625-2633.
Shorrocks B. 1972: Drosophila. Ginn, London, 144 pp.

Simpson S.J. \& RAUBENHEIMER D. 1993: A multilevel analysis of feeding-behaviour - the geometry of nutritional decisions. Phil. Trans. R. Soc. Lond. (B) 342: 381-402.

Simpson S.J., Sibly R.M., Lee K.P., Behmer S.T. \& Raubenheimer D. 2004: Optimal foraging when regulating intake of multiple nutrients. - Anim. Behav. 68: 1299-1311.

Simpson S.J., Le Couteur D.G. \& Raubenheimer D. 2015: Putting the balance back in diet. - Cell 161: 18-23.

Stamps J.A., Yang L.H., Morales V.M. \& Boundy-Mills K.L. 2012: Drosophila regulate yeast density and increase yeast community similarity in a natural substrate. - PLOS ONE 7(7): e42238, $11 \mathrm{pp}$.

Stomp M. van Dijk M.A., van Overzee H.M.J., Wortel M.T., Sigon C.A.M., Egas M.H., Hoogveld H., Gons H.J. \& HuisMAN J. 2008: The timescale of phenotypic plasticity and its impact on competition in fluctuating environments. - Am. Nat. 172: E169-E185.

Sultan S.E. \& Spencer H.G. 2002: Metapopulation structure favors plasticity over local adaptation. - Am. Nat. 160: 271-283.

Svilpe E. \& MatıušKova N. 2010: Influence of shiitake mushroom Lentinula edodes on reproduction of Drosophila melanogaster. - Proc. Latv. Acad. Sci. (B) 64: 223-228.

Trajković J., Pavković-Lučić S. \& Savić T. 2013: Mating success and wing morphometry in Drosophila melanogaster after longterm rearing on different diets. - Behaviour 150: 1431-1448.

TU M.-P. \& TATAR M. 2003: Juvenile diet restriction and the aging and reproduction of adult Drosophila melanogaster. - Aging Cell 2: 327-333.

United States Department of Agriculture. Agricultural ReSEARCh Service. USDA Food Composition Databases. URL: https://ndb.nal.usda.gov/ndb/.

Unckless R.L., Rottschaefer S.M. \& Lazzaro B.P. 2015: A genome-wide association study for nutritional indices in Drosophila. - G3 (Bethesda) 5: 417-425.

Via S., Gomulkiewicz R., de Jong G., Scheiner S.M., Schlichting C.D. \& VAN TIENDEREN P.H. 1995: Adaptive phenotypic plasticity: consensus and controversy. - Trends Ecol. Evol. 10: 212-217.

ViJendravarma R.K., Narasimha S. \& Kawecki T.J. 2011: Adaptation to larval malnutrition does not affect fluctuating assymmetry in Drosophila melanogaster. - Biol. J. Linn. Soc. 104: $19-28$.

Wang L. \& Clark A.G. 1995: Physiological genetics of the response to a high-sucrose diet by Drosophila melanogaster. Biochem. Genet. 33: 149-165.

Whitaker R., Gil M.P., Ding F., Tatar M., Helfand S.L. \& NerETTI N. 2014: Dietary switch reveals fast coordinated gene expression changes in Drosophila melanogaster. - Aging 6: 355-368.

Wright G.A. 2011: Appetitive learning: memories need calories. - Curr. Biol. 21: R301-302.

Xie J., De Clerce P., Pan C., Li H., Zhang Y. \& Pang H. 2015: Larval nutrition-induced plasticity affects reproduction and gene expression of the ladybeetle, Cryptolaemus montrouzieri. - BMC Evol. Biol. 15: 276, 9 pp.

Received December 5, 2016; revised and accepted March 23, 2017 Published online April 18, 2017 